\title{
Mechanisms for Interfacial Reactions between Liquid Sn-3.5Ag Solders and $\mathrm{Cu}$ Substrates
}

\author{
T.H. CHUANG,${ }^{1,2}$ H.M. WU, ${ }^{1}$ M.D. CHENG,${ }^{1}$ S.Y. CHANG,${ }^{1}$ and S.F. YEN \\ 1.-Institute of Materials Science and Engineering, National Taiwan University, Taipei 106, \\ Taiwan. 2.-E-mail: tunghan@ccms.ntu.edu.tw
}

Intermetallic compounds formed during the soldering reactions between $\mathrm{Sn}$ $3.5 \mathrm{Ag}$ and $\mathrm{Cu}$ at temperatures ranging from $250^{\circ} \mathrm{C}$ to $375^{\circ} \mathrm{C}$ are investigated. The results indicate that scallop-shaped $\eta-\mathrm{Cu}_{6}\left(\mathrm{Sn}_{0.933} \mathrm{Ag}_{0.007}\right)_{5}$ intermetallics grow from the $\mathrm{Sn}-3.5 \mathrm{Ag} / \mathrm{Cu}$ interface toward the solder matrix accompanied by $\mathrm{Cu}$ dissolution. Following prolonged or higher temperature reactions, $\varepsilon-\mathrm{Cu}_{3}$ $\left(\mathrm{Sn}_{0.996} \mathrm{Ag}_{0.004}\right)$ intermetallic layers appear behind the $\mathrm{Cu}_{6}\left(\mathrm{Sn}_{0.933} \mathrm{Ag}_{0.007}\right)_{5}$ scallops. The growth of these interfacial intermetallics is governed by a kinetic relation: $\Delta \mathrm{X}=\mathrm{t}^{\mathrm{n}}$, where the $\mathrm{n}$ values for $\eta$ and $\varepsilon$ intermetallics are 0.75 and 0.96 , respectively. The mechanisms for such nonparabolic growth of interfacial intermetallics during the liquid/solid reactions between $\mathrm{Sn}-3.5 \mathrm{Ag}$ solders and $\mathrm{Cu}$ substrates are probed.

Key words: $\mathrm{Sn}-3.5 \mathrm{Ag} / \mathrm{Cu}$, soldering reactions, intermetallic compounds, nonparabolic growth kinetics

\section{INTRODUCTION}

Copper is widely used in a sputtering target assembly as the material for backing plates. Upon the depletion of the target material, the $\mathrm{Cu}$ backing plate is debonded from the used target and recycled by being soldered with a new one. Out of environmental concerns, Sn-3.5Ag has been regarded as a promising $\mathrm{Pb}$-free solder because of the merits of high strength, good creep resistance, improved thermal fatigue life, low cost, and ideal wettability with $\mathrm{Cu}$ substrates. ${ }^{1}$ During the soldering reaction, intermetallic compounds are known to form at the interfaces, thereby attaining the bonding effect between the target material and solder. However, an overgrowth of interfacial intermetallics can induce cracking in the rebonded target assembly. ${ }^{2}$ Thus, vital information may be obtained for such an application through the identification of intermetallic phases and analysis of their growth kinetics during the interfacial reactions between the liquid Sn-3.5Ag solders and $\mathrm{Cu}$ backing plates.

The solid/solid reactions of $\mathrm{Sn}-3.5 \mathrm{Ag}$ and other Sn-based solders with $\mathrm{Cu}$ substrates, which result in the formation of scallop-shaped $\mathrm{Cu}_{6} \mathrm{Sn}_{5}$ intermetallic

(Received April 8, 2003; accepted August 12, 2003) compounds at the interfaces, have been investigated extensively. ${ }^{3-7}$ As noted by these reports, the intermetallic growths are diffusion-controlled and governed by a parabolic kinetic relation. However, studies on liquid/solid reactions for the related soldering systems over a wide temperature range are scarce, while opinions on mechanisms for the intermetallic growths in this case are varied. ${ }^{8-15}$ In this present study, the interfacial reactions between liquid $\mathrm{Sn}-3.5 \mathrm{Ag}$ solders and $\mathrm{Cu}$ substrates take place at temperatures ranging from $250^{\circ} \mathrm{C}$ to $375^{\circ} \mathrm{C}$ for $10-75 \mathrm{~min}$. After the reaction, the morphology and chemical compositions of the intermetallic compounds are probed and identified. The kinetics of intermetallic growth at the interfaces is analyzed through measurement of the intermetallic layer thickness at various reaction temperatures for various times, whereby the mechanisms for the formation of intermetallics at the $\mathrm{Sn}-3.5 \mathrm{Ag} / \mathrm{Cu}$ interface during the soldering reaction are investigated.

\section{EXPERIMENTAL}

The Sn-3.5Ag (wt.\%) solder was prepared by having pure Sn (99.9\%) and $\mathrm{Ag}(99.95 \%)$ encapsulated in a quartz tube under a vacuum of $10^{-5}$ torr and melted at $600^{\circ} \mathrm{C}$. The ingot was homogenized at $100^{\circ} \mathrm{C}$ for $50 \mathrm{~h}$ and then rolled into $0.5-\mathrm{mm}$ foil. Copper substrates with dimensions $8 \mathrm{~mm} \times 12 \mathrm{~mm}$ were 
cut from a 1-mm $\mathrm{Cu}$ plate (99.9\% purity), ground with $\mathrm{SiC}$ paper, and polished with $1-\mu \mathrm{m}$ and $0.3-\mu \mathrm{m}$ $\mathrm{Al}_{2} \mathrm{O}_{3}$ powders. For the study of interfacial reactions, the $\mathrm{Sn}-3.5 \mathrm{Ag}$ foils were placed on $\mathrm{Cu}$ substrates that had been dipped in a rosin mildly activated-type flux. The $\mathrm{Sn}-3.5 \mathrm{Ag} / \mathrm{Cu}$ couples were then heated in an infrared furnace under a vacuum of $10^{-3}$ torr. Soldering reactions were carried out at temperatures between $250^{\circ} \mathrm{C}$ and $375^{\circ} \mathrm{C}$ for various times. After reaction, the specimens were cooled to room temperature in $2 \mathrm{~min}$ via a water-cooling system installed within the furnace.

The soldered specimens were then cross-sectioned, ground, and polished. The morphology of intermetallic compounds formed in the solder and at the $\mathrm{Sn}-3.5 \mathrm{Ag} / \mathrm{Cu}$ interface was observed by scanning electron microscopy (SEM). The chemical compositions were identified using energy dispersive $\mathrm{x}$-ray spectroscopy (EDX). To clarify the mechanism of intermetallic formation during the liquid/solid interfacial reaction, a formerly developed marking technique was adopted: ${ }^{16}$ the surface of the solid substrate was partially sputter-coated with a Ta thin film (approximately 1,000 $\AA$ in thickness). Because the Ta thin film does not react with the $\mathrm{Sn}-3.5 \mathrm{Ag}$ liquid solder and the $\mathrm{Cu}$ substrate, it acted as a reaction marker to identify the original $\mathrm{Sn}-3.5 \mathrm{Ag} / \mathrm{Cu}$ interface. For kinetics analysis, the maximum migration distance of reaction front for each intermetallic scallop was measured. The average value of a minimum of 30 measurements for each soldering condition (per reaction temperature and time) was determined to signify the intermetallic thickness $(\Delta \mathrm{X})$. By applying this method, any error in measurement caused by the stripping of certain intermetallic scallops away from the interface could be mitigated.

\section{RESULTS AND DISCUSSION}

The microstructure of the as-cast Sn-3.5Ag solder is shown in Fig. 1; it contains many fine particles embedded in the Sn-rich matrix. The chemical com-

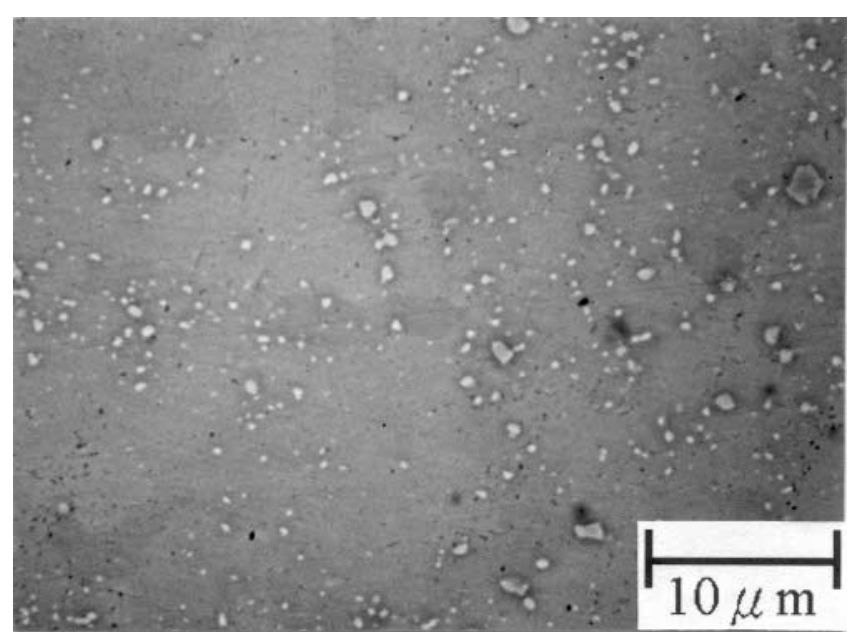

Fig. 1. Microstructure of the as-cast $\mathrm{Sn}-3.5 \mathrm{Ag}$ solder containing fine $\mathrm{Ag}_{3} \mathrm{Sn}$ precipitates embedded in the $\mathrm{Sn}-0.6 \mathrm{Ag}$ matrix. position (at.\%) of these fine particles is identified as $\mathrm{Ag}: \mathrm{Sn}=74.3: 25.7$, which corresponds to the $\mathrm{Ag}_{3} \mathrm{Sn}$ phase. The formation of such $\mathrm{Ag}_{3} \mathrm{Sn}$ precipitates causes the composition (wt.\%) of the matrix to deviate from $\mathrm{Sn}-3.5 \mathrm{Ag}$ to $\mathrm{Sn}-0.6 \mathrm{Ag}$. Differential scanning calorimetry (DSC) analyses (Fig. 2) reconfirm the eutectic composition of this solder, which possesses a melting temperature of $220^{\circ} \mathrm{C}$.

Figure 3 shows the morphology of the intermetallic compounds formed at the $\mathrm{Sn}-3.5 \mathrm{Ag} / \mathrm{Cu}$ interfaces after soldering reactions at $250^{\circ} \mathrm{C}$ for various times; the intermetallics appear in scallop shape and grow with an increase of time into the $\mathrm{Sn}-3.5 \mathrm{Ag}$ solder. The EDX analyses (Table I) indicate that the composition (at.\%) of these scallop-shaped intermetallics is $\mathrm{Cu}: \mathrm{Sn}: \mathrm{Ag}=54.40: 45.39: 0.31$, which corresponds to the $\eta-\mathrm{Cu}_{6}\left(\mathrm{Sn}_{0.993} \mathrm{Ag}_{0.007}\right)_{5}$ phase. Following prolonged soldering reactions, a thin layer of intermetallic compound appears at the $\mathrm{Cu}_{6}\left(\mathrm{Sn}_{0.993} \mathrm{Ag}_{0.007}\right)_{5} / \mathrm{Cu}$ interface. The composition (at.\%, given also by Table I) of these thin intermetallics is $\mathrm{Cu}: \mathrm{Sn}: \mathrm{Ag}=$ 75.21:24.70:0.09, which corresponds to the $\varepsilon-\mathrm{Cu}_{3}$ $\left(\mathrm{Sn}_{0.996} \mathrm{Ag}_{0.004}\right)$ phase. Along with the formation of $\eta$ and $\varepsilon$ phases at the interfaces, a large number of fine $\mathrm{Ag}_{3} \mathrm{Sn}$ particles precipitated in the solder matrix. The composition of the solder matrix as analyzed is $\mathrm{Sn}: \mathrm{Ag}: \mathrm{Cu}=98.30: 1.59: 0.11$ (wt.\%) or 97.96:1.83:0.21 (at.\%).

As the soldering temperature is increased to $300^{\circ} \mathrm{C}$, the interfacial $\eta$ and $\varepsilon$ intermetallics grow more rapidly (Fig. 4). However, the compositions of both intermetallic phases are similar to those soldered at $250^{\circ} \mathrm{C}$, as listed in Table I. Figure 4 also indicates that this higher temperature caused the number of $\mathrm{Ag}_{3} \mathrm{Sn}$ particles to rise. It has been shown that $\mathrm{Cu}$ can dissolve rapidly in $\mathrm{Sn}$ solders. The increase of $\mathrm{Cu}$ dissolution with increasing temperature leads to a decline of $\mathrm{Ag}$ solubility in $\mathrm{Sn}-3.5 \mathrm{Ag}$, which, in turn, causes more $\mathrm{Ag}_{3} \mathrm{Sn}$ particles to precipitate in the solder matrix. In addition to these fine $\mathrm{Ag}_{3} \mathrm{Sn}$ precipitates, a number of large intermetallic bands of the same composition as the $\mathrm{Ag}_{3} \mathrm{Sn}$

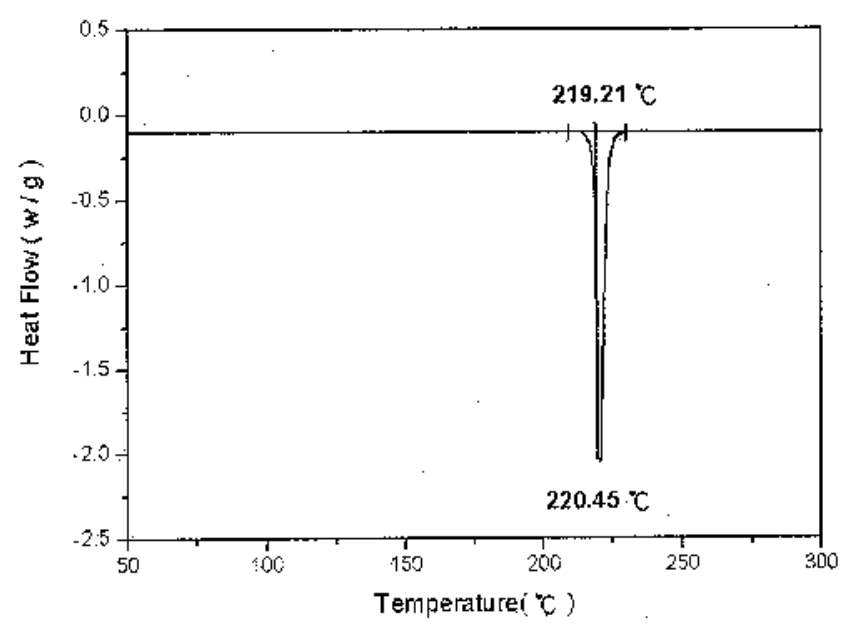

Fig. 2. DSC analysis of the eutectic Sn-3.5Ag solder. 

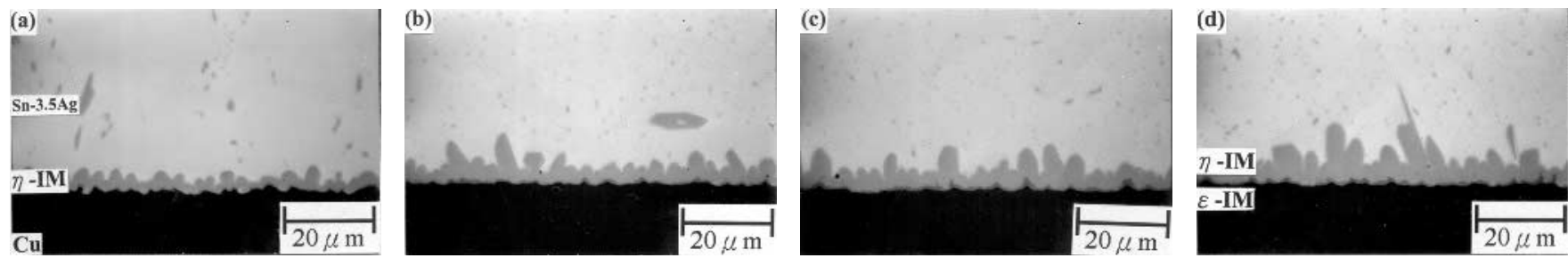

Fig. 3. Morphology of the intermetallic compounds formed during the interfacial reactions between liquid Sn-3.5Ag solders and Cu substrates at $250^{\circ} \mathrm{C}$ for (a) $30 \mathrm{~min}$, (b) $45 \mathrm{~min}$, (c) $60 \mathrm{~min}$, and (d) $75 \mathrm{~min}$.

Table I. Chemical Compositions (At.\%) of Intermetallic Compounds (IMs) Formed during Interfacial Reactions between Liquid Sn-3.5Ag Solders and Cu Substrates at Various Temperatures

\begin{tabular}{|c|c|c|c|c|c|}
\hline Temperature & IM Positions & IM Phases & $\mathbf{C u}$ & Sn & Ag \\
\hline \multirow{4}{*}{$250^{\circ} \mathrm{C}$} & \multirow{2}{*}{$\mathrm{Sn}-3.5 \mathrm{Ag} / \mathrm{Cu}$ interface } & $\eta$ phase & 54.40 & 45.39 & 0.31 \\
\hline & & $\varepsilon$ phase & 75.21 & 24.70 & 0.09 \\
\hline & \multirow{2}{*}{ Sn-3.5Ag solder } & $\eta$ phase & 54.25 & 45.42 & 0.33 \\
\hline & & $\varepsilon$ phase & - & - & - \\
\hline \multirow{4}{*}{$300^{\circ} \mathrm{C}$} & \multirow{2}{*}{$\mathrm{Sn}-3.5 \mathrm{Ag} / \mathrm{Cu}$ interface } & $\eta$ phase & 54.92 & 44.80 & 0.28 \\
\hline & & $\varepsilon$ phase & 74.61 & 25.27 & 0.12 \\
\hline & \multirow{2}{*}{ Sn-3.5Ag solder } & $\eta$ phase & 54.40 & 45.23 & 0.37 \\
\hline & & $\varepsilon$ phase & - & - & - \\
\hline \multirow{4}{*}{$375^{\circ} \mathrm{C}$} & \multirow{2}{*}{$\mathrm{Sn}-3.5 \mathrm{Ag} / \mathrm{Cu}$ interface } & $\eta$ phase & 55.15 & 44.56 & 0.29 \\
\hline & & $\varepsilon$ phase & 75.85 & 24.08 & 0.08 \\
\hline & \multirow{2}{*}{ Sn-3.5Ag solder } & $\eta$ phase & 54.52 & 45.18 & 0.30 \\
\hline & & $\varepsilon$ phase & - & - & - \\
\hline
\end{tabular}
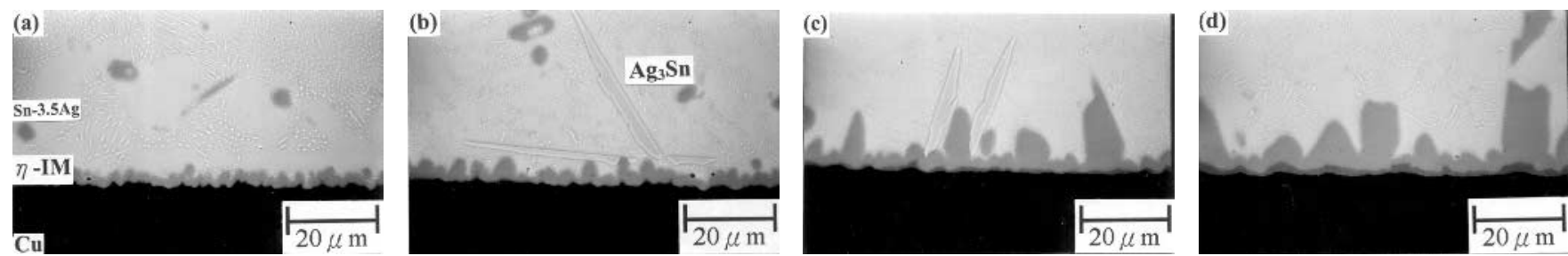

Fig. 4. Morphology of the intermetallic compounds formed during the interfacial reactions between liquid Sn-3.5Ag solders and Cu substrates at $300^{\circ} \mathrm{C}$ for (a) $10 \mathrm{~min}$, (b) $15 \mathrm{~min}$, (c) $30 \mathrm{~min}$, and (d) $60 \mathrm{~min}$.

fine particles can also be found in Fig. 4, which tend to appear in the vicinity of interfacial $\eta$ intermetallics. The formation of such intermetallic bands is believed to be a result of the increase in $\mathrm{Cu}$ dissolution at higher temperatures that simultaneously triggers the decrease of the $\mathrm{Ag}$ solubility in solder. Consequently, excessive $\mathrm{Ag}$ precipitates out to form large intermetallic bands during the solidification of the $\mathrm{Sn}-3.5 \mathrm{Ag}$ solder. The precipitation of fine $\mathrm{Ag}_{3} \mathrm{Sn}$ particles can strengthen the solder matrix, while the appearance of large $\mathrm{Ag}_{3} \mathrm{Sn}$ intermetallic bands is known to reduce the fatigue resistance in solder joints. ${ }^{17}$ The severe rate of $\mathrm{Cu}$ dissolution into the solder can be further evidenced by Fig. 5, as the original interface has been marked by partial surface sputtering of a Ta thin film on the Cu substrate. The interface migrates toward the $\mathrm{Cu}$ substrate. At the migrating interface, scallop-shaped $\eta$ intermetallics grow toward the solder matrix where many fine $\mathrm{Ag}_{3} \mathrm{Sn}$ particles are dispersed. Along with the formation of interfacial intermetallic scallops, the dissolved $\mathrm{Cu}$ atoms precipitate to form coarse islands in the solder. In the vicinity of these coarse

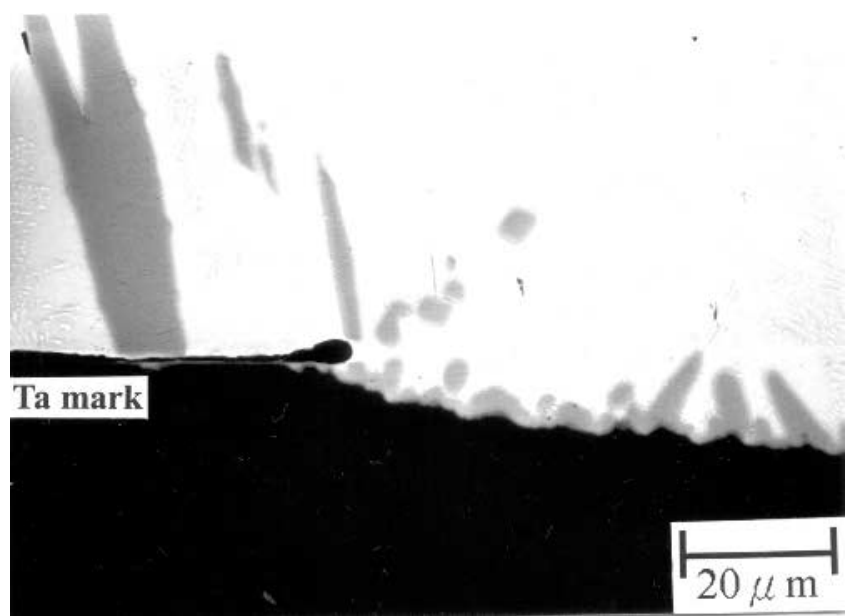

Fig. 5. Interface migration during the reaction between the liquid $\mathrm{Sn}-3.5 \mathrm{Ag}$ solder and Cu substrate at $300^{\circ} \mathrm{C}$ for $30 \mathrm{~min}$.

$\eta$-phase islands, $\mathrm{Ag}_{3} \mathrm{Sn}$ precipitation-free zones can be observed.

Figures 6 and 7 reveal the dramatic growth of scallop-shaped $\eta$ intermetallics with reaction time 

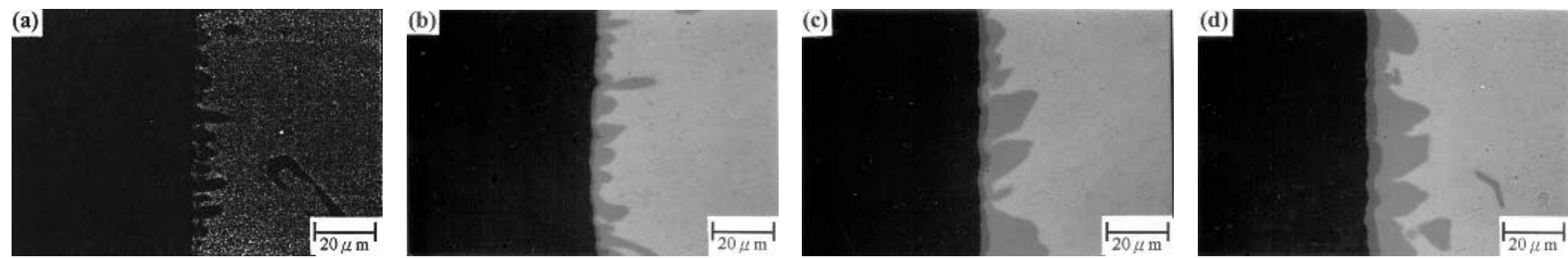

Fig. 6. Morphology of the intermetallic compounds formed during the interfacial reactions between liquid $\mathrm{Sn}-3.5 \mathrm{Ag}$ solders and $\mathrm{Cu}$ substrates at $325^{\circ} \mathrm{C}$ for (a) $15 \mathrm{~min}$, (b) $30 \mathrm{~min}$, (c) $60 \mathrm{~min}$, and (d) $120 \mathrm{~min}$.
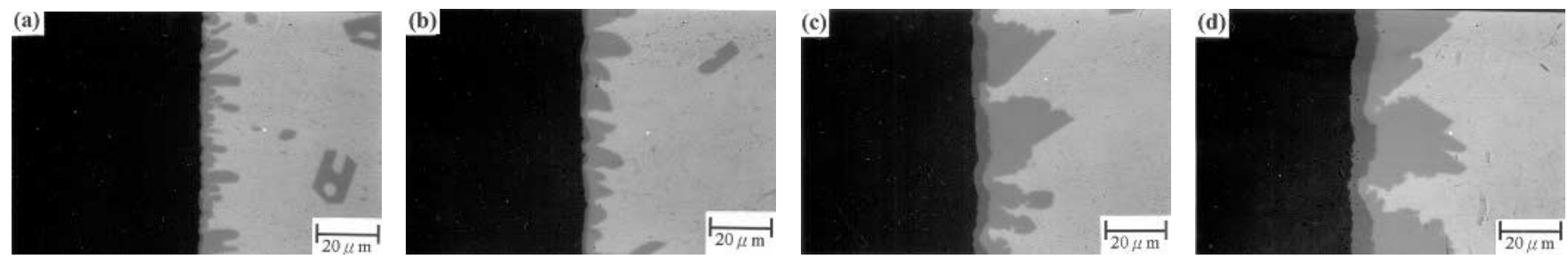

Fig. 7. Morphology of the intermetallic compounds formed during the interfacial reactions between liquid $\mathrm{Sn}-3.5 \mathrm{Ag}$ solders and $\mathrm{Cu}$ substrates at $350^{\circ} \mathrm{C}$ for (a) $15 \mathrm{~min}$, (b) $30 \mathrm{~min}$, (c) $60 \mathrm{~min}$, and (d) $120 \mathrm{~min}$.
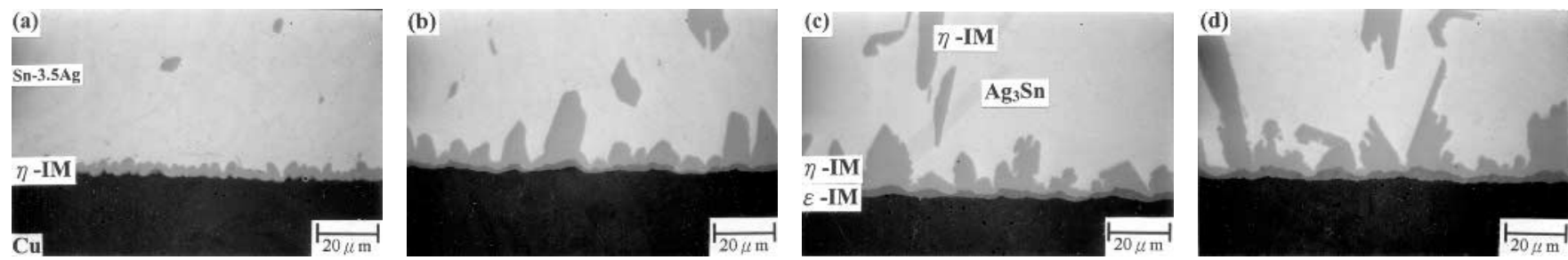

Fig. 8. Morphology of the intermetallic compounds formed during the interfacial reactions between liquid $\mathrm{Sn}-3.5 \mathrm{Ag}$ solders and $\mathrm{Cu}$ substrates at various temperatures for $30 \mathrm{~min}$ : (a) $275^{\circ} \mathrm{C}$, (b) $325^{\circ} \mathrm{C}$, (c) $350^{\circ} \mathrm{C}$, and (d) $375^{\circ} \mathrm{C}$.

at higher temperatures. It is worth noticing that the $\eta$-intermetallic compounds exhibit a tendency to elongate into the solder matrix without narrowing the grooves between intermetallic scallops. Figures 6 and 7 also show that a certain amount of coarse $\eta$-intermetallic scallops float into the solder matrix. It is believed that the detachment of these $\eta$-intermetallic islands from the interfaces into the solder matrix keeps the grooves between the remaining interfacial $\eta$ scallops "unclosed." Such an "unclosed-groove" mechanism for intermetallic growth during soldering reactions is further verified in Fig. 8, as the grooves exist even up to the temperature of $375^{\circ} \mathrm{C}$ in spite of the growth of interfacial intermetallics, which is correlated to the detachment and floating of some $\eta$-intermetallic islands into the solder matrix. From Figs. 6-8, the growth profile for the reaction fronts of $\varepsilon$ intermetallics coincides with that for $\eta$ scallops, i.e., the $\varepsilon$ intermetallics at the top of the $\eta$ scallops tend to grow faster, while the $\varepsilon$ intermetallics that remain behind the grooves are much thinner.

Figure 9 shows log plots for the thickness of $\eta-\mathrm{Cu}_{6}\left(\mathrm{Sn}_{0.993} \mathrm{Ag}_{0.007}\right)_{5}$ intermetallics formed during the interfacial reactions between liquid $\mathrm{Sn}-3.5 \mathrm{Ag}$ solders and $\mathrm{Cu}$ substrates at various temperatures as a function of reaction time. The slopes in the plots give the $\mathrm{n}$ values of the kinetic relation: $\Delta \mathrm{X}=\mathrm{t}^{\mathrm{n}}$. The results indicate that the $\mathrm{n}$ values range from

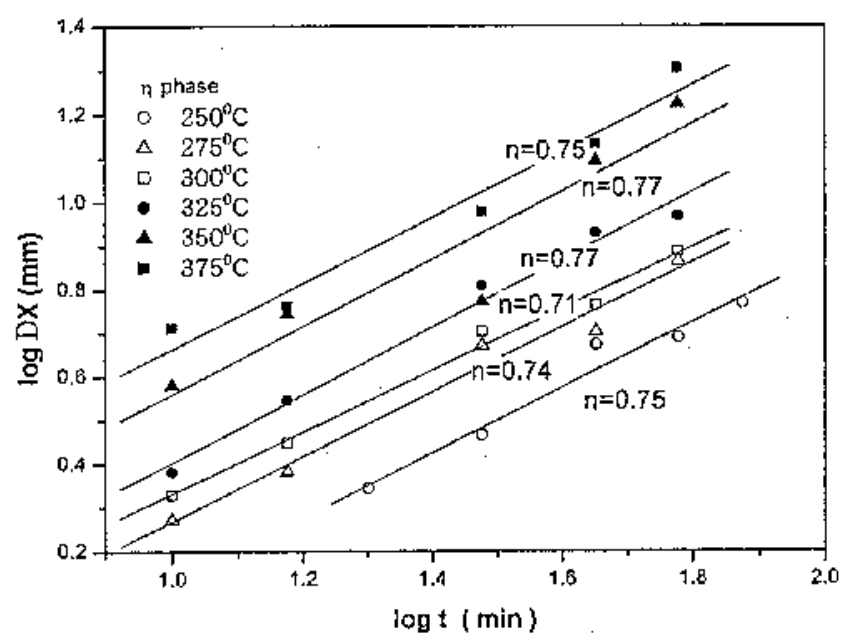

Fig. 9. Log plot of the thickness of $\eta-\mathrm{Cu}_{6}\left(\mathrm{Sn}_{0.993} \mathrm{Ag}_{0.07}\right)_{5}$ intermetallic compounds formed during the interfacial reactions between liquid Sn-3.5Ag solders and Cu substrates as a function of reaction time.

0.74 to 0.77 , with an average of 0.75 . The reactions do not quite follow the parabolic law (diffusion controlled). The nonparabolic growth kinetics of $\eta$ intermetallics at $\mathrm{Sn}-3.5 \mathrm{Ag}_{(\mathrm{l})} / \mathrm{Cu}_{(\mathrm{s})}$ interfaces should be related to the presence of the liquid grooves between $\eta$-intermetallic scallops during soldering reactions throughout the temperature range of $250-375^{\circ} \mathrm{C}$. In this case, $\mathrm{Cu}$ dissolves into the grooves and diffuses through those liquid paths to 


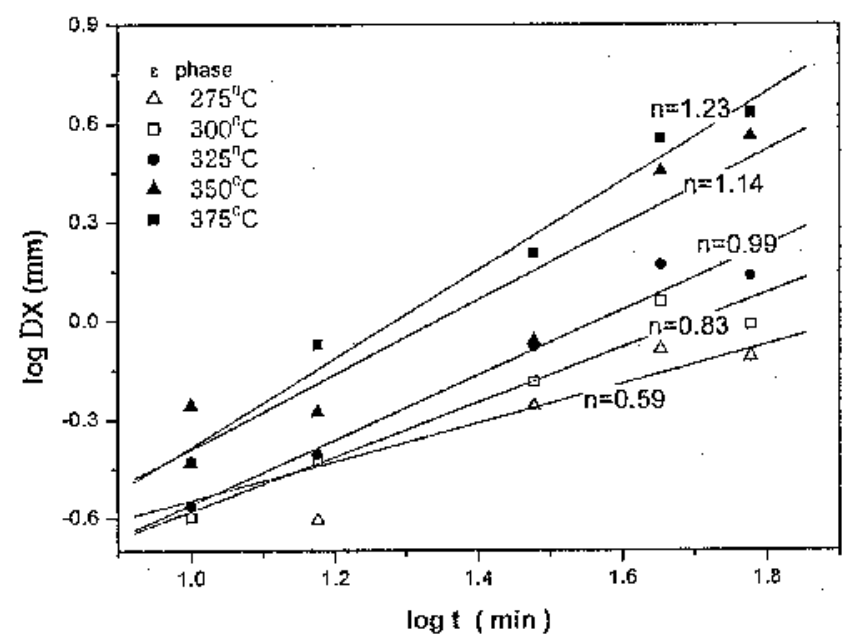

Fig. 10. Log plot of the thickness of $\varepsilon-\mathrm{Cu}_{3}\left(\mathrm{Sn}_{0.996} \mathrm{Ag}_{0.004}\right)$ intermetallic compounds formed during the interfacial reactions between liquid $\mathrm{Sn}-3.5 \mathrm{Ag}$ solders and $\mathrm{Cu}$ substrates as a function of reaction time.

react with $\mathrm{Sn}$ atoms at the front of the $\eta$ scallops. For the solid/solid interfacial reactions of $\mathrm{Sn} / \mathrm{Cu}$ couples, parabolic growth kinetics has often been reported. It is the absence of such liquid grooves (fast diffusion paths) that should be responsible for this disparity in growth kinetics.

The $\mathrm{n}$ values for the growth kinetics of $\varepsilon-\mathrm{Cu}_{3}$ $\left(\mathrm{Sn}_{0.996} \mathrm{Ag}_{0.004}\right)$ intermetallics were calculated from the $\log$ plots in Fig. 10, which range from 0.59 to 1.23 (average 0.96). The linear kinetic relation reveals that the reaction is interface-controlled. The formation of $\varepsilon-\mathrm{Cu}_{3}\left(\mathrm{Sn}_{0.996} \mathrm{Ag}_{0.004}\right)$ intermetallic compounds is known to result from the reaction: $\mathrm{Cu}(\mathrm{Sn}, \mathrm{Ag})+9 \mathrm{Cu} \rightarrow \mathrm{Cu}_{3}(\mathrm{Sn}, \mathrm{Ag})$. A comparison of Fig. 4a with $\mathrm{d}$ shows that the $\mathrm{Cu}$ fronts ( $\eta$ intermetallic/Cu substrate interfaces) are quite uneven (Fig. 4a) before the formation of $\varepsilon$ intermetallics, but with the appearance of the $\varepsilon$ intermetallics (viewed as $\varepsilon$ intermetallic/Cu substrate interfaces in Fig. 4d), they are much smoother. This phenomenon implies that the $\mathrm{Cu}$ atoms have been reserved originally in the $\mathrm{Cu}$ hills beneath the $\eta$ scallops and react later with $\eta$ intermetallics to create the $\varepsilon$ intermetallics. The rate-limiting step in the formation of $\varepsilon$ intermetallics is, therefore, the local release of $\mathrm{Cu}$ atoms from the $\mathrm{Cu}$ hills into the $\eta$ scallops and explains the resultant interface-controlled reaction for this case.

In a study of interfacial reactions between liquid $\mathrm{Sn}-37 \mathrm{~Pb}$ solders and $\mathrm{Cu}$ substrates, Kim et al. ${ }^{8}$ and Kim and $\mathrm{Tu}^{9}$ found that the growth of $\mathrm{Cu}_{6} \mathrm{Sn}_{5}$ intermetallic compounds followed the relation $\Delta \mathrm{X}=\mathrm{t}^{1 / 3}$, they attributed such growth kinetics of intermetallics at the $\mathrm{Sn}-37 \mathrm{~Pb} / \mathrm{Cu}$ interfaces to the ripening reaction of $\mathrm{Cu}_{6} \mathrm{Sn}_{5}$ scallops. The soldering reactions in our case were conducted at much higher temperatures for longer times when compared with those in the study of Kim and $\mathrm{Tu},{ }^{9}$ and the $\eta$ intermetallic scallops have anisotropically elongated toward the solder matrix, strongly indicative of the likely presence of the ripening effect during the earlier stages of the reactions. However, certain $\eta$ intermetallics can be extruded out of the interfaces through the ripening of neighboring scallops, resulting in the appearance of lengthened intermetallic scallops at the interfaces together with the grooves left in between. The discrepancy between the results presented here and the study of Kim and $\mathrm{Tu}^{9}$ on intermetallic growth kinetics can thus be clarified.

On the other hand, Bader and Gust studied the growth kinetics of solid-liquid interdiffusion between $\mathrm{Cu}$ and $\mathrm{Sn}$ thin films. ${ }^{10}$ The $\mathrm{Cu}_{6} \mathrm{Sn}_{5}$ intermetallic compound was reported to grow in the ratio of $(\mathrm{t})^{\mathrm{n}}$, where $\mathrm{n}$ was given as 0.20 and 0.25 , respectively, for the reaction temperatures of $240^{\circ} \mathrm{C}$ and $300^{\circ} \mathrm{C}$. According to their explanation, $\mathrm{Cu}$ and $\mathrm{Sn}$ atoms diffused through the grooves between the $\mathrm{Cu}_{6} \mathrm{Sn}_{5}$ crystallites at the onset of the $\mathrm{Cu}_{(\mathrm{s})} / \mathrm{Sn}_{(1)}$ interfacial reactions. Concurrent with the growth of $\mathrm{Cu}_{6} \mathrm{Sn}_{5}$, the grooves become narrower, and the diffusion of $\mathrm{Cu}$ and $\mathrm{Sn}$ slows down. It is reasonable for the resulting $\mathrm{n}$ values to become smaller than 0.5 . However, it is invalid to apply their conclusion to the bulk solder case in our study. As shown in Figs. 6 and 7, the grooves stay unclosed because of the floating of certain $\eta$-intermetallic scallops into the liquid Sn-3.5Ag solder matrix. The fast diffusion paths for $\mathrm{Cu}$ atoms exhibit little change with the gaining of reaction time, which helps explain away the disparity in our study and Bader and Gust's result of intermetallic growth kinetics.

Liang et al. ${ }^{18}$ studied the liquid-solid reactions of $\mathrm{Cu} / \mathrm{Sn} / \mathrm{Au}$ thin-film couples at temperatures between $250^{\circ} \mathrm{C}$ and $400^{\circ} \mathrm{C}$ from $10 \mathrm{~min}$ to $40 \mathrm{~min}$. Owing to the low thickness of liquid Sn $(4 \mu \mathrm{m})$, the $\eta$-intermetallic scallops could not be stripped away, leaving the grooves along the interface "closed" after such prolonged reactions. In this case, the reactioncontrolling step in the growth of $\mathrm{Cu}_{6} \mathrm{Sn}_{5}$ intermetallic compounds was the diffusion of $\mathrm{Cu}$ and $\mathrm{Sn}$ atoms through the continuous $\mathrm{Cu}_{6} \mathrm{Sn}_{5}$ layer.

$\mathrm{Bae}$ and $\mathrm{Kim}^{11}$ investigated the interdiffusion process during the soldering reactions between liquid $\mathrm{Sn}-3.5 \mathrm{Ag}$ solders and $\mathrm{Cu}$ substrates at $270^{\circ} \mathrm{C}$ and $350^{\circ} \mathrm{C}$ for $3-10 \mathrm{~min}$. They found Sn played the dominant diffusion role in intermetallic formation, so was the case for solid/solid reactions at $\mathrm{Sn} / \mathrm{Cu}$ interfaces. Although kinetics data is lacking to shed some light in the discrepancy between their results and ours, it should be pointed out that the $\mathrm{Ag}$ content of their $\eta$ intermetallics at $\mathrm{Sn}-3.5 \mathrm{Ag} / \mathrm{Cu}$ interfaces ranges from 0.66 at.\% to 0.97 at.\% (about threefold more than what our study obtains, as shown by Table I). In their case, the $\mathrm{Ag}_{3} \mathrm{Sn}$ precipitation was absent, replaced by an increase in the $\mathrm{Ag}$ content of the solder in the vicinity of interfacial $\eta$ intermetallics to the relatively high values of 9.51-11.03 at.\%. In our case, the as-cast solder matrix contains only 0.60 wt.\% (0.67 at.\%) Ag because of the precipitation of $\mathrm{Ag}_{3} \mathrm{Sn}$. After soldering 
reaction, our solder matrix contains 1.59 wt.\% (1.83 at.\%) $\mathrm{Ag}$ and 0.11 wt.\% (0.21 at.\%) Cu. Because the element $\mathrm{Ag}$ has been reported to impact $\mathrm{Cu}$ dissolution in $\mathrm{Sn},{ }^{19}$ the disparity in the Ag content of the solder matrix may be responsible for the different mechanisms for intermetallic formation in the two studies.

\section{CONCLUSIONS}

During the liquid-solid reactions between Sn$3.5 \mathrm{Ag}$ solders and $\mathrm{Cu}$ substrates at temperatures ranging from $250^{\circ} \mathrm{C}$ to $375^{\circ} \mathrm{C}, \mathrm{Cu}$ dissolution into the solder causes the original interfaces to migrate toward the $\mathrm{Cu}$ substrates. Along with the formation of scallop-shaped $\eta-\mathrm{Cu}_{6}\left(\mathrm{Sn}_{0.993} \mathrm{Ag}_{0.007}\right)_{5}$ and $\varepsilon-\mathrm{Cu}_{3}$ $\left(\mathrm{Sn}_{0.996} \mathrm{Ag}_{0.004}\right)$ intermetallics, fine $\mathrm{Ag}_{3} \mathrm{Sn}$ particles and coarse $\eta$-intermetallic islands in large quantities appear in the solder matrix. At temperatures greater than $300^{\circ} \mathrm{C}$, large $\mathrm{Ag}_{3} \mathrm{Sn}$ intermetallic bands can be found in the solder. Kinetics analyses show that the intermetallic growth at $\mathrm{Sn}-3.5 \mathrm{Ag} / \mathrm{Cu}$ interfaces follows the relation: $\Delta \mathrm{X}=\mathrm{t}^{\mathrm{n}}$, where the $\mathrm{n}$ values for $\eta$ and $\varepsilon$ intermetallics are 0.75 and 0.96 , respectively. These results disagree with the parabolic intermetallic-growth kinetics reported by many studies on the solid-solid interfacial reactions of $\mathrm{Sn}-\mathrm{Cu}$ couples. The deviation in this study can be attributed to the unclosed liquid grooves between intermetallic scallops, which act as fast diffusion paths for $\mathrm{Cu}$ atoms to react with solders at the intermetallic fronts. The discrepancy in our research results of reaction kinetics and those reported by Kim et al. and Bader and Gust for liquid-solid reactions between $\mathrm{Sn}-37 \mathrm{~Pb}$ (or $\mathrm{Sn}$ ) solders and $\mathrm{Cu}$ substrates can also be attributed to varied reaction conditions leading to varied effects of liquid grooves upon the intermetallic growth.

\section{ACKNOWLEDGEMENTS}

Special thanks go to National Science Council, Taiwan, for sponsoring this research under Grant No. NSC-90-2216-E002-032.

\section{REFERENCES}

1. J. Glazer, Int. Mater. Rev. 40, 65 (1995).

2. P.G. Harris and K.S. Chaggar, Soldering Surf. Mount Technol. 10, 38 (1998)

3. P.T. Vianco, K.L. Erickson, and P.L. Hopkins, J. Electron. Mater. 23, 721 (1994).

4. D.R. Flander, E.G. Jacobs, and R.F. Pinizzotto, J. Electron. Mater. 26, 883 (1997).

5. D.R. Frear and P.T. Vianco, Metall. Mater. Trans. A 25A, 1509 (1994).

6. W. Yang and R.W. Messler, Jr., J. Electron. Mater. 23, 765 (1994).

7. J. Haimovich, AMP J. Technol. 3, 46 (1993),

8. H.K. Kim, H.K. Liou, and K.N. Tu, Appl. Phys. Lett. 66, 18 (1995).

9. H.K. Kim and K.N. Tu, Phys. Rev. B53, 16027 (1996).

10. S. Bader and W. Gust, Acta Mater. Metall. 43, 1 (1995).

11. K.S. Bae and S.J. Kim, J. Electron, Mater. 30, 1452 (2001).

12. P.T. Vianco, P.F. Hlava, and A.C. Kilgo, J. Electron. Mater. 23, 583 (1994)

13. A. Hayashi, C.R. Kao, and Y.A. Chang, Scripta Mater. 37, 393 (1997).

14. S.W. Chen and Y.W. Yen, J. Electron. Mater. 28, 1203 (1999).

15. M. Schaefer, R.A. Fournelle, and J. Liang, J. Electron. Mater. 27, 1167 (1998).

16. Y.H. Tseng, M.S. Yeh, and T.H. Chuang, J. Electron. Mater. 28, 105 (1999).

17. K. Suganuma, K.S. Kim, and S.H. Huh, Int. Symp. on Microelectronics (Washington, DC: IMAPS, 2001), pp. 529-534

18. M.W. Liang, T.E. Hsieh, S.Y. Chang, and T.H. Chuang, J. Electron. Mater. 32, 952 (2003).

19. S. Chada, R.A. Fouruelle, W. Laub, and D. Shangguan, J. Electron. Mater. 29, 1214 (2000). 